\title{
7: 22540060-22544856
}

National Cancer Institute

\section{Source}

National Cancer Institute. 7: 22540060-22544856. NCI Thesaurus. Code C45136.

Physical location of IL6_Gene 